\title{
JURNAL EKONOMI EFEKTIF

\section{PERGERAKAN HARGA SAHAM PT ADARO ENERGY TBK (ADRO) PADA PENGUMUMAN DIVIDEN INTERIM TAHUN BUKU 2018}

\author{
${ }^{1}$ Sigit Purnomo, Veta Lidya Delimah Pasaribu \\ ${ }^{1}$ sigitpurnomo@gmail.com, vethalidya@yahoo.com
}

\begin{abstract}
ABSTRAK
Penelitian ini bertujuan 1) untuk mengetahui pengaruh EVA terhadap nilai perusahaan, 2) untuk mengetahui pengaruh MVA terhadap nilai perusahaan, 3) untuk mengetahui pengaruh EVA, MVA secara bersama-sama terhadap nilai perusahaan, dan 4) untuk mengetahui pengaruh nilai perusahaan dampaknya pada retun saham bank umum yang go public di Bursa Efek Indonesia periode tahun 2006-2015.penelitian yang dilakukan di Bursa Efek Indonesia periode tahun 2006-2015 memiliki 43 bank sebagai populasi penelitian. Dalam penelitian ini dipilih secara purposive sampling sebanyak 5 bank umum yang go public dengan kriteria,yaitu: 1)mempublikasikan laporan keuangan selama periode 2006-2015,2) mempublikasikan laporan harga saham periode 2006-2015. Adapun bank-bank yang menjadi sample penelitian adalah Bank Tabungan Negara, Bank Central Asia, Bank Negara Indonesia, Bank Rakyat Indonesia dan Bank Mandiri. Data yang digunakan adalah data panel. Sedangkan teknik analisis yang digunakan adalah analisis regresi berganda, dengan melakukan uji t,uji $\mathrm{F}$, dan asumsi klasik. Hasil penelitian menunjukan bahwa 1) ada pengaruh EVA terhadap nilai peruahaan, yang ditunjukan dengan nilai $t$ hitung lebih besar $t$ tabel dimana pengaruhnya berbanding terbalik atau negatif dan kuat, 2) ada pengaruh MVA terhadap nilai saham yang ditunjukkan dengan nilai t hitung lebih besar $t$ tabel dengan nilai korelasi positif dan kuat, dan 4) nilai perusahaan tidak berdampak pada retrun saham bank umum yang go public di Bursa Efek Indonesia periode tahun 2006-2015 baik secara parsial ataupun simultan. Imi ditunjukkan dari nilai t hitung yang lebih kecil t tabel dan F hitung lebih kecil dari $\mathrm{F}$ tabel.
\end{abstract}

\section{Kata kunci: Harga Saham, Dividen Interim}

\section{ABSTRACT}

The purpose 1) to determine the effect of EVA on firm value, 2) to determine the effect of $M V A$ on firm value, 3) to determine the effect of EVA, MVA together on company value, and 4) to determine the effect of corporate value on the impact on returns shares of commercial banks that went public on the Indonesia Stock Exchange in the period 2006-2015. Research conducted on the Indonesia Stock Exchange in the period 2006-2015 has 43 banks as research populations. In this study, purposive sampling was chosen as many as 5 commercial banks that went public with criteria, namely: 1) publishing the financial statements for the period 20062015 , 2) publishing the stock price report for the period 2006-2015. The banks that become the research sample are the National Savings Bank, Central Asia Bank, Bank Negara Indonesia, Bank Rakyat Indonesia and Bank Mandiri. The data used is panel data. While the analysis technique used is multiple regression analysis, by t-test, F-test and classic assumptions. The 
results showed that 1) there is an influence of EVA on the value of the company, which is indicated by the value of t arithmetic greater t table where the effect is inversely proportional or negative and strong, 2) there is the effect of MVA on the value of the stock as indicated by the value of t arithmetic greater t table with a positive and strong correlation value, and 4) the value of the company does not have an impact on the retrun shares of commercial banks that went public on the Indonesia Stock Exchange for the period 2006-2015, either partially or simultaneously. This is shown from the smaller $t$ count value $t$ table and $F$ count smaller than F table.

\section{Keywords: Stock Prices, Interim Dividends}

\section{PENDAhULUAN}

\section{A. Latar Belakang}

Berdasarkan peraturan Bank Indonesia Nomor 6/10/PBI/2004 tentang sistem penilaian tingkat kesehatan Bank Umumnya yaitu bahwa kesehatan suatu bank merupakan kepentingan semua pihak yang terkait, baik pemilik, pengelola bank, masyarakat pengguna jasa bank dan Bank Indonesia selaku otoritas pengawasan bank, menurut "pasal 3 peraturan BI Nomor 6/10/PBI/2004 yang berbunyi penilaian tingkat kesehatan bank mencakup penilaian terhadap faktor-faktor permodalan (capital),kualitas asset (asset quality), manajemen (manajemen), rentabilitas (earning), likuiditas (liquidity), dan sentitivitas terhadap resiko pasar (sensintivity to marek risk)". Sehingga faktor rentabilitas (earning) yang dipilih dalam pembahasan ini adalah sangat penting terhadap kelangsungan pertumbuhan bank agar tetap beroperasi dan menjalankan fungsi bank dengan baik. (Peraturan BI No. 6/10/PBI/2004).

Hal ini menandakan bahwa didalam perkembangannya, bank membutuhkan dana yang lebih besar. Banyak para pelaku perbankan berpendapat bahwa kekurangan dana tersebut menjadikan go public sehingga wadah terbaik untuk menghimpun dana investor dari penjualan saham dibursa efek Indonesia (BEI).

Kinerja keuangan suatu perusahaan dapat dinilai dengan mnggunakan beberapa alat analisis keuangan, salah satunya yaitu laporan keuangan dengan menggunakan pendekatan beberapa rasio keuangan misalnya rasio profitabilitas, rasio likuiditas, rasio laverage dan lainlain. Laporan keuangan merupakan salah satu sumber informasi penting disamping informasi lain seperti informasi industry, kondisi perekonomian, pangsa pasar perusahaan, kualitas manajemen dan lainnya (Hanafi, 2005:51).

Suatu perusahaan go public senantiasa memberikan informasi terhadap kinerja keuangan perusahaan sebagai bahan pertimbangan investor dalam melakukan keputusan investasi yang akan dilakukan. Dari informasi tersebut sedikit banyak perusahaan dapat menginformasikan keadaan yang terjadi dalam perusahaan tersebut. Dengan diantaranya fakotr-faktor internal perusahaan berupa rasio-rasio kinerja keuangan perusahaan yang dapat dianalisis oleh investor kinerja keuangan inilah yang digunakan sebagai signal (signaling theory) bagi investor untuk mengetahui tingkat kinerja perusahaan.

Berdaarkan latar belakang yang telah diuraikan diatas,penulis tertarik untuk melakukan penelitian dan menganalisis kinerja perusahaan Bank Umurm yang telah go public di Bursa Efek Indonesia (BEI) menggunakan metode Economic Value Added (EVA) dan Market Value Added (MVA),serta mengetahui pengaruh penilaian kinerja perusahaan dengan metode Econominc Value Added (EVA) dan Market Value Added (MVA) terhadap harga saham yang diberi judul "Analisis Pengaruh Economic Value Added dan Market Value Added terhadap Nilai Perusahaan (PBV) dan Dampaknya terhadap Return Saham Pada Bank Umum Yang Terdaftar Dibursa Efek Indonesia Periode tahun 2006-2015”. . 


\section{B. Perumusan Masalah}

Berdasarkan identifikasi dan pembahasan masalah diatas, dapat dirumuskan masalah penelitian adalah :

1. Apakah ada pengaruh EVA terhadap nilai perusahaan pada bank umum yang go public di Bursa Efek Indonesia periode tahun 2006-2015?

2. Apakah ada pengaruh MVA terhadap nilai perusahaan pada bank umum yang go public di Bursa Efek Indonesia periode tahun 2006-2015?

3. Apakah ada pengaruh EVA, MVA secara bersama-sama terhadap Nilai perusahaan pada bank umum yang go public di Bursa Efek Indonesia periode tahun 2006-2015?

4. Apakah nilai perusahaan bedampak pada return saham bank umum yang go public di Bursa Efek Indonesia periode tahun 2006-2015?

\section{Tujuan Penelitian}

Tujuan dari penelitian ini adalah :

1. Untuk mengetahui pengaruh EVA terhadap Nilai Perusahaan pada bank umum yang go public di Bursa Efek Indonesia periode tahun 2006-2015.

2. Untuk mengetahui pengaruh MVA terhadap Nilai Perusahaan pada bank umum yang go public di Bursa Efek Indonesia periode tahun 2006-2015.

3. Untuk mengetahui pengaruh EVA, MVA secara bersama-sama terhadap Nilai Perusahaan pada bank umum yang go public di Bursa Efek Indonesia periode tahun 2006-2015.

4. Untuk mengetahui pengaruh Nilai Perusahaan dampaknya pada retun saham bank umum yang go public di Bursa Efek Indonesia periode tahun 2006-2015.

\section{TINJAUAN PUSTAKA}

\section{A. Perusahaan Go-Publik}

Go-Publik artinya adalah penawaran efek/surat berharga kepada masyarakat umum baik perorangan maupun lembaga untuk pertama kalinya "pertama kali" adalah pihak emiten/perusahaan menerbitkan efek untuk pertama kalinya dan melakukan penjualan efek dipasar perdana.Go-Publik biasanya juga dikatakan sebagai emisi atau penawaran umum.

\section{B. Economic Value Added (EVA)}

Menurut Robert N. Anthony \& Vijay Govindarajan (2002:249), Economic Value Added (EVA) merupakan jumlah uang bukan rasio yang diperoleh dengan mengurangkan beban modal (capital charge) dari laba bersih operasi (net operating profit). Menurut Amin Widjaja Tunggal (2001:1), metode Economic Value Added (EVA) di Indonesia dikenal dengan metode nilai tambah ekonomi (NITAMI) merupakan suatu sistem manajemen keuangan untuk mengukur laba ekonomi dalam suatu perusahaan yang mengatakan, bahwa kesejahteraan hanya dapat tercipta jika perusahaan mampu memenuhi semua biaya operasi (operating cost) dan biaya modal (cost of capital).

\section{Market Value Added (MVA)}

Menurut Steward (dalam Rahayu, 2007:32), Market Vakue Added (MVA) suatu pengukuran kinerja yang tepat untuk menilai sukses tidaknya perusahaan dalam menciptakan kekayaan bagi pemiliknya. Jadi, kekayaan atau kesejahteraan pemilik perusahaan (pemegang saham) akan bertambah bila Market Value Added (MVA) bertambah. Peningkatan Market Value Added (MVA) dapat dilakukan dengan cara meningkatkan Economic Value Added (EVA) yang merupakan pengukuran internal kinerja operasional tahunan, dengan demikian Economic Value Added (EVA) mempunyai hubungan yang kuat dengan Market Value Added (MVA). 


\section{Return Saham}

Saham adalah tanda penyertaan dil atau pemilikan seseorang atau lembaga dalam suatu perusahaan (Hidayat, 2010:96). Saham dibagi menjadi dua yaitu saham biasa (common stock) dan saham preferen (preffered stock). Dari kedua jenis saham diatas, yang paling banyak ditransaksikan dibursa adalah jenis saham preferen terletak pada hak dan kewajiban pemegang saham. Biasanya saham preferen diterbetikan secara terbatas.

1. saham biasa (common stock)

Saham biasa adalah saham dimana pemegang saham yang memilikinya mewakili kepemilikan diperusahaan sebesar modal yang ditanamkan (Hidayat,2010:96).

2. saham preferen (preffered stock)

Saham prefere adalah bagian saham yang memiliki tambahan hak melebihi sahamsaham biasa. Para pemegang saham preferen akan mendapatkan dividen lebih dahulu dan juga memiliki hak suara lebih dibandingkan pemegang saham biasa.

Salah satu keuntungan dari memiliki saham adalah adanya return saham berupa capital gain. Return saham merupakan tingkat keuntungan yang akan diperoleh oleh investor yang menanamkan dananya dipasar modal. Return pada dasarnya dibagi dua jenis yaitu :

a) capital gain/loss

Diprolrh dari selisi harga investasi sekarang dengan harga sebelumnya. Jika harga investasi sekarang lebih tinggi dari harga investasi periode lalu berarti terjadi keuntungan modal (capital gain) dan sebaliknya.

b) Deviden

Nilai pendapatan bersih perusahaan setelah pajak dikurangi laba ditahan yang dibagikan kepada pemilik saham.

\section{E. Nilai Perusahaan (Value Of The Firm)}

Wahyudi Pawestri (2006) menyatakan bahwa nilai perusahaan yang dibentuk memalui investor nilai saham, sangat dipengaruhi oleh peluang investasi. Nilai perusahaan yang dibentuk melalui indikator nilai pasar saham sangat dipengaruhi denga peluang-peluang investasi. Adanya peluang investasi dapat memberikan sinyal positif tentang pertumbuhan perusahaan dimasa yang akan datang. Sehingga akan meningkatkan harga saham makan nilai perusahaan akan meningkat.

\section{F. Hipotesis Penelitian}

Sugiyono (2008:93) menyatakan bahwa hipotesa adalah jawaban sementara terhadap rumusan masalah dalam penelitian. Dikatakan sementara karena jawaban yang diberikan baru didasarkan teori -teori relevan. Belum berdasarkan fakta empiris yang diperoleh melalui pengumpulan data.

Berdasarkan model kerangka pemikiran yang telah diuraikan diatas, maka hipotesis yang diajukan sebagai jawaban sementara terhadap permasalahan penelitian ini adalah sebagai berikut :

1. $\mathrm{H}_{\mathrm{a} 1}$ : Terdapat Pengaruh EVA terhadap nilai perusahaan.

2. $\mathrm{H}_{\mathrm{a} 2}$ : Terdapat Pengaruh MVA terhadap nilai perusahaan.

3. $\mathrm{H}_{\mathrm{a} 3}$ : Secara Simultan pengaruh EVA dan MVA terhdap nilai.

4. $\mathrm{H}_{\mathrm{a} 4}$ : Terdapat pengaruh nilai perusahaan yang berdampak pada return saham.

\section{METODE PENELITIAN}

Penelitian ini mengambil lokasi pada Bursa Efek Indonesia (BEI). Ditetapkan diBursa Efek Insonesia sebagai tempat penelitian dengan mempertimbangkan bahwa BEI salah satu sentral merupakan penjualan saham perusahaan yang go public. BEI beralamat di gedung 
Bursa Efek Indonesia, Menara 1 Jl. Jend. Sudirman Kav 52-53 Jakarta Selatan 12190, Indonesia. Nomor telepon +62215150515 Fax : +62215150330 Email : callcenter@idx.co.id Website : www.idx.id Toll Free : 0800-100-9000 (Nasional). Penelitian mengambil data sekunder laporan keuangan dari perusahaan-perusahaan perbankan umum konversional go public yang terdapat diotoritas jasa keuangan (OJK) periode 2011- Desember 2015, melalui Webside: http/www.ojk.go.id dan hppt://www.sahamok.com.

Pengambilan sampel dilakukan berdasarkan metode purposive sampling yaitu teknik sampel dengan pertimbangan tertentu (Sugiyono,1999). Pengambilan sampeldengan metode ini bertujuan untuk mendapatkan sampel yang representatif sesuai dengan kriteria sampel, yaitu :

1. Perusahaan menertibkan laporan keuangan tahunan dari periode 31 Desember 2006 sampai dengan 31 Desember 2015

2. Perusahaan memiliki laporan harga saham selama 10 tahun berturut-turut yaitu tahun 2006 sampai tahun 2015

Berdasarkan kriteria atau pertimbangan yang telah ditetapkan dari tahun 2006-2015 dari seluruh populasi yang ada, maka yang memenuhi kriteria yang lebih ditentukan 5 bank yang memiliki 2 kriteria diatas, yaitu telah menerbitkan laporan keuangan selama 10 tahun berturutturut dan memiliki laporan harga saham selama 10 tahun pada periode 2006-2015.

\section{HASIL DAN PEMBAHASAN}

\section{A. Uji Hipotesis Dengan Analisis Regresi Data Panel Untuk Pengaruh EVA, MVA} Terhadap PBV

\section{Pengaruh EVA dan MVA terhadap PBV secara Parsial (uji t)}

Uji $t$ dalam regresi linier berganda dimaksudkan untuk menguji apakah parameter (koefisien regresi dan konstanta) yang diduga untuk mengestimasi persamaan / modal regresi linear berganda sudah merupakan parameter yang tepat atau belum. Maksudnya adalah paramwtwr twrsebut mampu menjelaskan perilaku variable bebas (independent) dalam mempengaruhi variabel dependen (terikat). Parameter yang diestimasikan dalam regresi linear meliputi intersep (konstanta) dan slope (koefisien regresi), sehingga uji t dimaksud adalah uji koefisien regresi.

Untuk melihat besarnya pengaruh EVA dan MVA Terhadap nilai perusahaan (PBV) secara parsial digunakam uji t. Apabila t hitung $>t$ tabel, maka tolak Ho dan dapat disimpulkan bahwa variabel independen berpengaruh secara nyata terhadap variabel dependen. Apabila t hitung $<\mathrm{t}$ tabel, maka $\mathrm{H}_{\mathrm{o}}$ diterima dan dapat disimpulkan bahwa variabel independen tidak mempengaruhi variabel dependen nya secara nyata. Apabila nilai probabilitas thitung lebih kecil dari tingkat kesalahan $(\alpha)$ sebesar 0,05 maka dapat dikatakan bahwa variabel bebas mempengaruhi signifikan terhadap variabel terikat. Sedangkan apabila nilai probabilitas t hitumg $>\alpha / 0,05$, maka dapat dikatakan bahwa variabel bebas tidak berpengaruh signifikan terhadap variabel terikat.

\section{a. Pengaruh EVA Terhadap Nilai Perusahaan (PBV)}

Berdasarkan tabel 4.15 diatas, hasil pengujian analisis regresi data penel secara persial menunjukkan hasil t-hitung variabel EVA adalah - 6,243. Sementara $t$ tab dengan $\alpha=5 \%$ dan df $(\mathrm{n}-\mathrm{k})=50-2=48$ maka t-tabel $(0,05: 48)=2,01$ sehingga $\mathrm{t}$ hitung $>\mathrm{t}$ tabel $(6,243>2,01)$, jadi $\mathrm{H}_{\mathrm{o}}$ ditolak dan $\mathrm{H}_{1}$ diterima,sehingga dapat disimpulkan bahwa variabel independen EVA berpengaruh terhadap PBV. Sedangkan nilai probabilitas EVA $<0,05(0,000<0,05)$ maka dapat dikatakan bahwa terdapat berpengaruh secara signifikan dari variabel EVA terhadap nilai perusahaan (PBV).

\section{b. Pengaruh MVA Terhadap Nilai Perusahaan (PBV)}


Berdasarkan tabel 4.15 diatas, hasil pengujian analisis regresi data penel secara parsial menunjukkan hasil t-hitung variabel MVA adalah -10,067, tanda positif artinya memiliki hubungan positif atau berbanding lurus. Sementara t tabel dengan $\alpha=5 \%$ dan df $(n-k)=50-2=48$ maka t-tabel $(0,05: 48)=2,01$ sehingga $t$ hitung $>\mathrm{t}$ tabel $(10,067$ $>2,01$ ), jadi Ho ditolak dan $\mathrm{H}_{1}$ diterima, sehingga dapat disimpulkan bahwa variabel independen MVA berpengaruh secara nyata terhadap variabel dependen PBV. Kemudian nilai probabilitas MVA $<0,05(0,000<0,05)$ maka dapat dikatakan bahwa terdapat berpengarub secara signifikan dari variabel MVA terhadap nilau perusahaan (PBV).

\section{Pengaruh EVA dan MVA terhadap nilai perusahaan (PBV) secara simultan (Uji-} F)

Uji F Digunakan untuk mengetahui apakah variabel independen secara bersamasama berpengaruh terhadap variabel dependen atau untuk mengetahui apakah model regresi dapat digunakan untuk memprediksi variabel dependen atau tidak.

Apabila nilai $\mathrm{F}$ hitung $>\mathrm{F}$ Tabel maka Ho ditolak dan $\mathrm{H}_{1}$ diterima, sehingga dapat disimpulkan bahwa variabel independen secara simultan mempengaruhi variabel dependennya. Apabila nilai $\mathrm{F}$ hitung $<\mathrm{F}$ tabel maka $\mathrm{H}_{\mathrm{o}}$ diterima dan $\mathrm{H}_{1}$ ditolak, sehingga dapat disimpulkan bahwa variabel independen secara simultan tidak mempengaruhi variabel dependennya. Kemudian apabila nilai probabilitas F Hitung lebih besar dari tingkat kesalahan $\alpha=5 \%$ maka dapat dikatakan bahwa variabel independen nya tidak mempengaruhi secara signifikan terhadap variabel dependen. Adapun model data panel yang digunakan dalam uji ini adalah model fixed effect.

Berdasarkan hasil perhitungan dengan menggunakan program Eviews 9 yang ditunjukkan pada tabel 4.15 diatas, nilai $F$ Hitung sebesar 52,941 dan nilai $F$ tabel dengan tingkat kesalahan 5\% dan dfl $(\mathrm{k})=2$, df2 $(\mathrm{n}-\mathrm{k})=(50-2)=48$, didapatkan $\mathrm{F}$ tabel sebesar 3,32. Dengan demikian $F$ hitung $>\mathrm{F}$ tabel $(52,941>3,32)$ jadi $\mathrm{H}_{\mathrm{o}}$ ditolak dan $\mathrm{H}_{1}$ diterima dapat di simpulkan bahwa variabel independen secara simultan mempengaruhi variabel dependennya. Kemudian terlihat dari nilai probabilitas dari tabel diatas yaitu sebesar 0,000 yang lebih kecil dari tingkat signifikansi 0,05 sehingga $\mathrm{H}_{\mathrm{o}}$ ditolak $\mathrm{H}_{1}$ diterima. Hal ini berarti bahwa EVA dan MVA secara bersama-sama (simultan) mempunyai pengaruh yang signifikan terhadap nilai perusahaan (PBV).

\section{Pengujian Koefisien Determinasi (Adjusted R-Squared)}

Koefisien determinasi dalam regresi data panel digunakan untuk mengetahui presentase sumbangan pengaruh variabel independen secara simultan terhadap variabel dependen. Koefisien ini menunjukkan seberaoa besar pengaruh variabel independen yang digunakan dalam model mampu menjelaskan variabel dependen. Koefisien determinasi EVA dan MVA dapat dilihat pada tabel 4.15. Berdasarkan tabel tersebut besarnya angka adjusted R-squared adalah 0,679 . $\mathrm{H}$ ini menunjukkan bahwa presentase sumbangan pengaruh variabel independen terhadap variabel dependen adalah sebesar $67,9 \%$. Sedangkan sisanya 32,1\% lainnya dipengaruhi faktor lain diluar model regresi tersebut.

\section{Persamaan Model Regresi EVA Dan MVA Terhadap Nilai Perusahaan (PBV)}

Penelitian dengan regresi data panel ini digunakan untuk melihat pengaruh antara variabel independen terhadap variabel dependen. Hubungan flukuasi variabel dependen dan faktor-faktor lain yang mempengaruhinya dapat diformulasikan. Berdasarkan perhitungan, diperoleh persanaan model regreau sebagai berikut. 
Nilai perusahaan $=1,953-(7,65 \mathrm{E}-05) \mathrm{EVA}+(3,00 \mathrm{E}-11) \mathrm{MVA}$

Dari persamaan tersebut, dapat diuraikan sebagai berikut.

a. a konstanta sebesar 1,953 berarti bahwa apabila tidak ada variabel EVA dan MVA maka besarnya nilai perusahaan (PBV) sebesar 1,953 dengan asumsi faktor - faktor lain adalah konstan.

b. $b_{1}=$ sebesar -7,65E-05 adalah menunjukkan bahwa EVA mempunyai hubungan negatif (terbalik) antara EVA dengan nilai perusahaan. Hasil ini mengidentifikasikan bahwa jika variabel EVA meningkat satu satuan unit maka akan diikuti penurunan dari nilai perusahaan sebesar satu satuan unit dengan asumsi variabel yang lainnya konstan.

c. $\mathrm{b}_{2}=3,04 \mathrm{E}-11$ adalah menunjukkan hubungan positif (searah) antara MVA dengan nilai perusahaan. Hasil ini mengidentifikasikan bahwa jika variabel MVA meningkat satu satuan unit maka akan diikuti peningkatan dari nilai perusahaan sebesar satu satuan unit dengan asumsi variabel yang lainnya konstan.

\section{B. Estimasi Model / Persamaan (Equation Estimation) Regresi Data Panel Untuk Variabel Nilai Perusahaan (PBV) dan Retrun Saham}

Estimasi model / persamaan (Equation Estimation) digunakan untuk melakukan analisis empiris yang tidak mungkin dilakukan jika hanya menggunakan data time series atau cross section. Dengan mengkombinasikan data time series dan cross section maka panel data memiliki beberapa keunggulan (Gujarati, 2004). Berikut ini merupakan hasil dari estimasi model regresi data panel.

\section{Common Effect Model (CEM)}

Berdasarkan hasil perhitungan dengan menggunakan eviews yang ditunjukkan tab 4.15 nilai $\mathrm{F}$ hitung 0,17 sementara $\mathrm{F}$ tabel dengan tingkat signifikansi $5 \%$ dan df1 $=1$ dan df $2=49$ diperoleh $\mathrm{F}$ tabel $=4,04$. Karena $(017<4,04)$ jadi $\mathrm{H}_{\mathrm{o}}$ diterima dan $\mathrm{H}_{1}$ ditolak, dapat disimpulkan bahwa variabel dependen Return Saham. Kemudian nilai probabilitas dati tabel di atas yaitu sebesar 0,676 yang lebih besar dari tingkat signifikansi 0,05 sehingga $\mathrm{H}_{\mathrm{o}}$ diterima.

\section{Model Random Effect (RE)}

Model Random Effect (RE) hanya dapat diestimasikan pada saat jumlah perusahaan lebih banyak dari jumlah variabel. Berdasarkan tabel 4.16 dengan menggunakam mod random effect (RE) memiliki nilai konstanta sebesar 0,09, sedangkan untuk nilai koefisien regresi variabel PBV sebesar 0,011 sehingga persamaan regresinya dapat dituliskan sebagai berikut.

$$
\text { Retrun saham }=0,09+0,011 \text { PBV }
$$

a. Besarnya nilai konstamta sebesar 0,09 , berarti bahwa apabila tidak ada variabel PBV maka besarnya Retrun Saham sebesar 0,09 dengan asumsi faktor-faktor lain adalah konstan.

b. Koefisien regresi PBV sebesar 0,011 menunjukkan bahwa koefisien regresi PBV adalah positif yang berarti bahwa setiap kenaikan satu satuan unit akan menaikkan return saham satusatuan unit.

\section{Uji Hipotesis dengan Analisis Regresi Data Panel untuk Pengaruh PBV terhadap Return Saham}

Berdasarkan hasil perhitingan dengan menggunakan eviews yang ditunjukkan tabel 4.17, nilai $\mathrm{F}$ Hitung sebesar 0,176 sementara $\mathrm{F}$ Tabel dengan tingakt signifikansi $5 \%$ dan dfl $(\mathrm{k}-1)=$ 1 dan $\mathrm{df} 2=(\mathrm{n}-\mathrm{k})=48$ diperoleh $\mathrm{F}$ tabel $=4,04$. Karena $(0,176<4,04)$ jadi $\mathrm{H}_{\mathrm{o}}$ diterima dan $\mathrm{H}_{1}$ ditolak, dalat disimpulkan bahwa variabel PBV tidak memiliki pengaruh yang signifikan 
terhadap variabel dependen retrun saham. Kemudian nilai probabilitas dari tabel diatas yaitu sebesar 0,676 yang lebih besar dari tingkat signifikansi 0,05 sehingga $\mathrm{H}_{\mathrm{o}}$ diterima.

\section{KESIMPULAN DAN SARAN}

\section{A. Kesimpulan}

Berdasarkan hasil penelitian dan pembahasan diatas dapat disimpulkan beberapa hal sebagai berikut :

1. Ada pengaruh EVA terhadap nilai perusahaan pada bank umum yang go public di Bursa Efek Indonesia periode tahun 2006-2015 yang ditunjukan dengan nilai t hitung lebih besar $t$ tabel dimana pengaruhnya nerbanding terbalik atau negative dan kuat.

2. Ada pengaruh MVA terhadap nilai saham pada bank umum yang go public di Bursa Efek Indonesia periode tahun 2006-2015 yang ditunjukan dengan nilai $\mathrm{t}$ hitung lebih besar $\mathrm{t}$ tabel dengan nilai korelasi positif dan kuat.

3. Ada pengaruh EVA, MVA secara bersama-sama terhadap nilai saham pada bank umum yang go public di Bursa Efek Indonesia periode tahun 2006-2015, yang ditunjukan dengan nilai $\mathrm{F}$ hitung lebih besar dari $\mathrm{F}$ tabel dengan nilai korelasi positif dan kuat.

4. Nilai perusahaan tidak berdampak pada retrun saham bank umum yang go public di Bursa Efek Indonesia periode Tahun 2006-2015 baik secara parsial ataupun simultan.ini ditunjukan dari nilai thitung yang lebih kecil $\mathrm{t}$ tabel dan $\mathrm{F}$ hitung lebih kecil dari $\mathrm{F}$ tabel.

\section{B. Saran}

Berdasarkan pada hasil penelitian, penelitian menyarankan beberapa hal sebagai berikut.

1. Untuk menilai tingkat kesehatan suatu bank sebaiknya menggunakan Economic Value Added (EVA) dari pada rasio-rasio keuangan. Rasio-rasio keuangan yang baik belum tentu mencerminkan kondisi peeusahaan yang baik pula karena rasio-rasio keuangan tidak memperhitungkan biaya modal. Sedangkan dengan menggunakan EVA, kita dapat mengetahui nilai sebenarnya yang diciptakan oleh perusahaan karena EVA dalam perhitungannya memperhitungkan biaya modal. Disamping itu, disarankan untuk mempertimbangkan nilai MVA guna mengetahui dukungan para investor terhadap harga saham yang ada sehingga akan terjadi peningkatan harga saham yang ada sehingga akan terjadi peningkatan harga saham dan yang beredar dipasar.

2. Hendaknta masing-masing Bank umum yang terdaftar di Bursa Efek Indonesia tetap mempertahankan kinerja keuangannya yang sudah baik dengan tetap melakukan terobosan-terobosan positif untuk menarik minat dan dukungan investor.

\section{DAFTAR PUSTAKA}

Bunarto, JUliana. 2006. Analisis Economic Value Added (EVA) dan Market Value Added (MVA) terhadap harga saham perusahaan-perusahaan makanan dan minuman yang GoPublic. SKripsi. Surabaya: Universitas Kristen Petra.

Dwitayanti, Dwi. 2005 Analisis Pengaruh Economic Value Addes (EVA) terhadap Market Value Added (MVA) pada industri Manufaktur di Bursa Efek Jakarta.

Govindarajan, Vijay dan Robert N, Anthony. 2002 sistem pengendalian manajemen. Edisi I. Jakarta: Salemba Empat.

Hakim, Rahman. 2006. Perbandingan Nilai perusahaan keuangan perusahaan dengan Metode EVA, ROA, dan pengaruhnya terhadap Return saham pada perusahaan yang tergabung dengan indeks LQ45 di Bursa Efek Jakarta, Skripsi. Yogyakarta: Universitas Islam Indonesia.

Harahap, SofyanSyafri, 2003, teori Akuntansi, Jakarta: Bumi Aksara. 
Hendrata,Daniel 2001. Analisis Economic Value Addes (EVA) dan Market Value Added(MVA) sebagai alat pengukur nilai perusahaan perusahaa serta pengaruhnya terhadap harga saham Skripsi. Surabaya : Univeritas Kristen Petra.

Husnan, Saud. 2011. Dasar-Dasar Manajemen Keuangan. Yogyakarta : UPP STIM YKPN.

Ikatan Akuntan Indonesia . 2004, Standar Akuntansi Keuangan, Jakarta : Salemba Empat.

Jogiyanto, 2000. Teori Portofolio dan Analisis Intvestasi. Edisi II. yogyakarta BPFEUGM.

Mamduh, M.Hanafu. 2004. Manajemen Keuangan, Yogyakarta : BPFE.

Munawir, 2002. Analisis Laporan Keuangan, Yogyakarta : Liberty.

Nugroho, BhuonoAgung. 2005. Strategi Jitu Memilih Metode Statistik Penelitian dengan SPSS . Yogyakarta : ANDI

O'Byrne, F. StephendanS. David Young. 2001. Economic Value Added dan Manajemen Berdasarkan Nilai Panduan Praktis untuk Implementasi Jakarta : Salemba Empat.

Rahayu, MarianaSru 2007. Analisis Pengaruh EVA dan MVA terhadap Retrun Saham pada perusahaan Manufaktur di Bursa Efek Jakarta. Skripsi, Yogyakarta : Universitas Islam Indonesia.

Rangkuti, Freddy. 2001. Teknik Membuat Perencanaan Bisnis dan Analisis Kasus. Cetakan ketiga. Jakarta : Gramedua Pustaka Utama.

Sudikin \& Mundir. 2005. Metode penelitian : membimbing dan mengatur kesuksesan anda Dalam Penelitian. Insan Cendikia : Surabaya.

Sutrisno. 2000. Manajemen Keuangan Teori, Konsep, dan Aplikasi. Edisi 1, yogyakarta : Ekonosia.

T. W. Mulia 2002. Peneralan Konsep Eva sebagai Added Aproach dari Analisis Rasio Keuangan untuk Mengukur Nilai perusahaan PT Gudang Garam Kediri. Jurnal Manajemen dan Akuntansi.

Tandelilin, Erduardus. 2001. Pengaruh Investasi dan Manajemen Portofolio. Jurnal Manajemen. Yogyakarta : BPFEUGM 